\title{
The Impact of Remittances on Socio-Economic Development - The Case of Kosova
}

\section{Qëndresë Cuci}

MSc Cand., Faculty of Economics, University of Prishtina 'Hasan Prishtina' Republic of Kosova

\begin{abstract}
Another important indicator of a country's economic development is the inflation and the unemployment rate, and according to the latest report of Kosova Agency of Statistics, the percentage of unemployment in Kosova is around $30.9 \%$ and this is an indicator that the unemployment rate has been reduced compared to the previous years, on the other hand, the number of families receiving remittances is decreased for $2.6 \%$ compared to 2011 according to a ASK report.1 Also the number of startups in 2012 has increased to 7,8792 which created new jobs. So, remittances re very important especially for developing countries such as Kosova. Taking into consideration the fact that Kosova is in the development phase, and the standard of living is very low, the number of population seeking to migrate is increasing continuously. According to statistics, the number of male migrants is higher compared with female igrants and rural settlements have shown an increase in migration compared to urban settlements. Our community is convinced that diaspora is an indicator in the economic development of our country, such as skills development for knowledge that they would benefit from, education, for consumption and commercial investments, all these for a higher standard of living.
\end{abstract}

Keywords: remittances, migration, income growth, efficiency, sustainable development, economic growth, social welfare.

\section{Introduction}

The economic growth in 2008 in Kosova was generated by the private consumptions increase and public investments, that to a certain extent were financed by remittances and foreign assistance.

Thus, migration has important social, economic, and political impact at home and abroad, and the international migration is increasing more than ever before in Kosova.

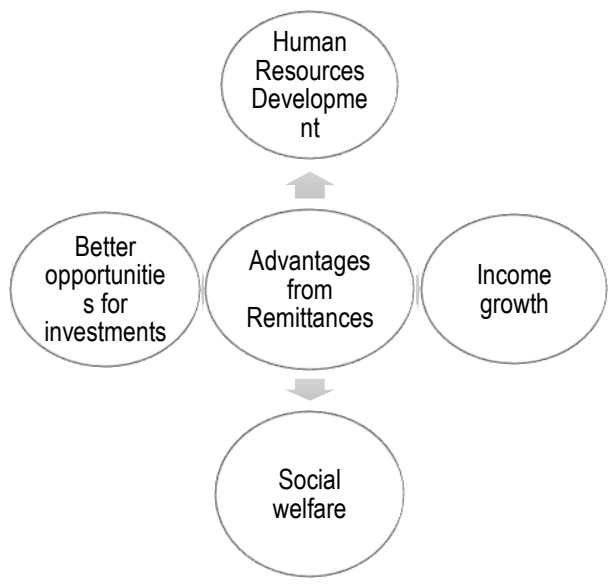


According to the authors of the influential book The Age of Migration (2003), Stephen Castles and Mark Miller, there can be few people in either industrialized or less developed countries today who do not have personal experience of migration (p. 5).

\section{Study objectives}

1. To reviews the effect of remittances on economic development as measured by GDP in Kosova during the period 2004-2013.

2. To review the Macroeconomic Impact of Remittances, an aggregate measure of economic growth;

3. To show the relationship of Remittances with other economic development key indicators such as incomes, consumption and investment;

4. To discuss the main features of labour migration and to generate an overall picture of current characteristics and trends;

5. To suggest regulatory frameworks, strategies and policies to improve economic growth.

\section{Methodological approach}

The methodogical approach of this study follows using Pearson Correlation technique to evaluate the gathered quantitative data, to analyze the Impact of Remittances on GDP growth, respectively the Impact of Remittances on Economic Growth of Kosova.

The used model for this study consists of two variables: Remittances (in EUR) and GDP with current prices (in EUR).

Quantitative data were gathered from World Bank, Central Bank of the Republic of Kosova, Statistical Agency of the Republic of Kosova and United Nations Development Programme.

\section{Description of Matrix Correlation}

$\mathrm{N}$ - This is the number of valid (i.e., non-missing) observations used in calculating the t-test.

Mean - This is the mean of the variable.

Std. Deviation - This is the standard deviation of the variable.

When Pearson's $r$ is close to 1

This means that there is a strong relationship between your two variables. This means that changes in one variable are strongly correlated with changes in the second variable.

When Pearson's $r$ is close to 0

This means that there is a weak relationship between your two variables. This means that changes in one variable are not correlated with changes in the second variable.

When Pearson's $r$ is positive $(+)$

This means that as one variable increases in value, the second variable also increase in value. Similarly, as one variable decreases in value, the second variable also decreases in value. This is called a positive correlation.

When Pearson's $r$ is negative (-) 
This means that as one variable increases in value, the second variable decreases in value. This is called a negative correlation.

Descriptive Statistics

\begin{tabular}{|l|l|l|l|}
\hline & Mean & Std. Deviation & N \\
\hline GDP Current Prices & 4916400.000 & & 1 \\
\hline Remittances & 457000.0000 & $\cdot$ & 1 \\
\hline
\end{tabular}

Correlations

The matrix shows that Remittances have a positive influence in GDP growth.

Hence, this study presents Remittances as a factor that lead to economic growth, and has a positive Impact on Economic growth in Kosova.

\begin{tabular}{|ll|l|l|}
\hline & & Remittances & GDP Current Prices \\
\hline Pearson Correlation & GDP Current Prices & 1.000 & . \\
& Remittances & & 1.000 \\
\hline Sig. (1-tailed) & GDP Current Prices & & \\
& Remittances & & 1 \\
\hline $\mathrm{N}$ & GDP Current Prices & 1 & 1 \\
\hline
\end{tabular}

\section{Remittances, Economic Development \& Social Welfare}

1. How important are Remittances for our country? Positive \& negative effects

Kosova as a developing country is very dependant on remittances, it is as one of the country's largest financial inflows and are used in different means, as consumption, clothes, education services and investments. A great number of Kosovars have migrated abroad before the war of 1999, and they still continue to do so mostly for political and economical reasons, but most of them or expressed in percentage around $86 \%$ migrated for economical reasons. An important fact which we should pay attention is the fact that those remittances have a low usage in education services and investments, and the creation of monetary and fiscal policies for promotion of investments should be a top priority of government authorities and agencies. Remittances are a great contribution in the overall GDP in Kosova which count for $9.3 \%$ of overall GDP according to a survey on remittances of family economies in 2013 of Kosova Agency of Statistics in cooperation with the United Nations Development Programme (UNDP).

Although remittances are very important for developing countries, however except for positive effects, remittances are considered to have negative effects also, such as the discrouragment of population for employment, as their remittances are slightly higher than the income from employment, but still for Kosova's case the negative effects are not a problem, because more than half of the population is between $15-24$ years old or $55 \%$ of population able to work. Another negative factor is the loss of human resources capital from migration to other countries.

Alternatively, remittances can boost economic growth by increasing incomes, consumption and investment.

Political and economical factors are the main factors of migration in foreign countries, since that major social indicators are the powerty and low incomes in the country. The average salary in Kosova in 2012, was 272.00 Euro, and the main source of income in Kosova are salaries, whereas prices of consumption are very high compared with the standard of living, price of consumption as yearly average is calculated in $7.3 \%$. 
Table 1. Remittances received in Kosova during the years

\begin{tabular}{|l|l|l|l|l|l|}
\hline Year & $\begin{array}{l}\text { Average of remittances } \\
\text { in cash, goods and } \\
\text { services }\end{array}$ & $\begin{array}{l}\text { Average } \\
\text { spending of } \\
\text { emigrants in Euro }\end{array}$ & $\begin{array}{l}\text { Total of annual } \\
\text { remittances in cash, } \\
\text { goods and services }\end{array}$ & $\begin{array}{l}\text { Total of annual } \\
\text { spending of } \\
\text { emigrants }\end{array}$ & $\begin{array}{l}\text { Total of annual } \\
\text { received } \\
\text { remittances }\end{array}$ \\
\hline 2010 & $€ 3.331$ & $€ 2.757$ & $€ 174.3$ million & $€ 272.4$ million & $€ 446.7$ million \\
\hline 2011 & $€ 2.136$ & $€ 2.352$ & $€ 157.5$ million & $€ 214.1$ million & $€ 371.6$ million \\
\hline 2012 & $€ 2.829$ & $€ 2.715$ & $€ 186.9$ million & $€ 270.1$ million & $€ 457$ million \\
\hline
\end{tabular}

Source: Survey on remittances of family economies 2013' Kosova Agency of Statistics and UNDP

Kosova is in the list of 139 developing countries, and below are presented the flow of remittances and their influence in economic growth in developing countries for period of 2012-2014, where it is evident that remittances play an important economic role, and remittances are the main indicators of their development. In 2010, there was an increase in remittances from $8 \%$ from 2010. Economic crisis and the high unemployment rate are the main factors that influence migration and remittances according to the expert for migration, remitancess and economic development from Group for Economic Development of World Bank. As seen in the below chart, Kosova remittances count for 17\% of GDP in 2010.

Fig. 1 Remittances in \% of GDP 2010

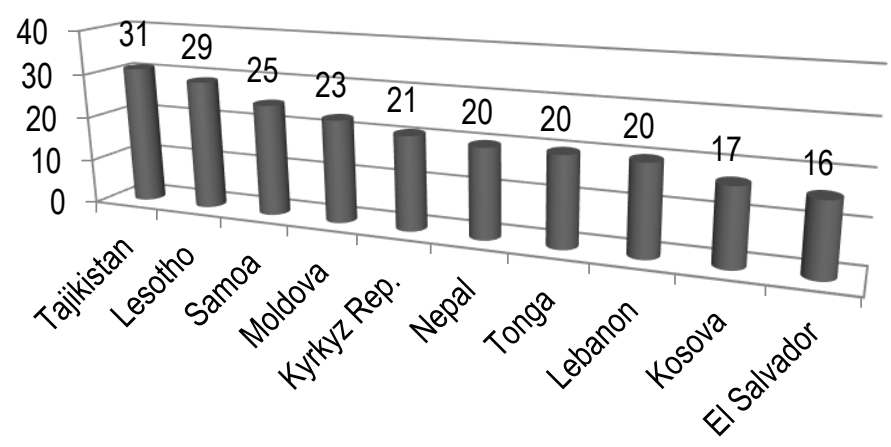

Source: Outlook for migration and remittances 2012-14, Dilip Ratha, World Bank

2. Remittances, other economic indicators and GDP growth

Remittances are considered as economic growth generators and GDP growth which is calculated in the income of a country and are an indicator of economic growth or standoff of a country. According to Kosova Agency of Statistics, economic growth in Kosova in 2012 has been positive and reached 2,721 Euro per capita, which has been generated from increase of private consumption and public investments which are made possible thanks to the remittances, and other bank loans, government spending for political and economical reasons.

\section{Economical indicators}

Real growth for GDP $2.5 \%$ (2012)

GDP per capita (in Euro) 2,721 (2012)

Consumer price index (annual average) 7.3\%

Export of goods (in thousands euro) 276,100 (2012)

Import of goods (in thousands euro) 2,507,609 (2012) 
Number of new enterprises established 7,879

Source: Economical statistics 2011-2012

According to statistical data of Kosova Agency of Statistics, remittances in Kosova marked an increase of $23.1 \%$ compared with the previous year, which was 457 million Euro, or $9.3 \%$ of Gross Domestic Product, a fact that tells the remittances have an important meaning and are a big contributor in sustainable economic development and improvement of social welfare for population of Kosova, but an important issue is the allocation of this income, the way people spend them, whether consumption, education or investment!

Fig. 2 Gross Domestic Product (GDP) and Remittances in 2012 (in million Euro)

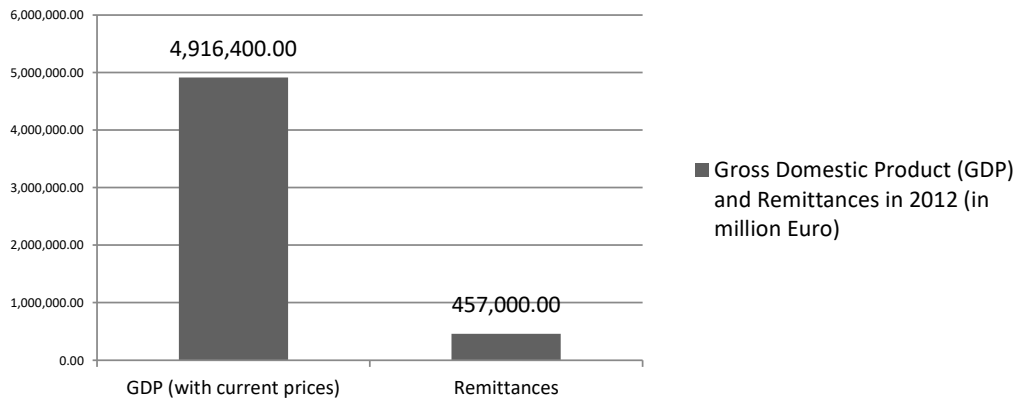

Source: KAS ‘Report of Gross Domestic Product in access of spending 2004-2012

3. Migration, main reasons for migration

An advantage of Kosova population in rapport with migration is the knowledge of foreign languages. Statistics have shown that at least $44.5 \%$ of the population speak at least one foreign language, which facilitates the adoption in the country of migration. A concerning aspect for Kosova government is the illegal migration, an aspect that government authorities are working to prevent, and promote legal migration in compliance with European standards and Kosova law for migration. Effective management of migration would encourage mobility in the region, this could be done through different trainings of international organisaitons in collaboration with the Ministry of Foreign Affairs for raising awareness of citizens for concequences that come as a result of illegal migration. According to a report of Central Bank of Kosova around $60 \%$ of diaspora population have permanent residency status, $34 \%$ have temporary residency, and only $1.2 \%$ are on study permits. The following analysis tell that te main reason for migration is the economic purpose with a percentage of $48.8 \%$ an only $1.2 \%$ migrate for study purposes, because economic conditions are a barrier to study abroad.

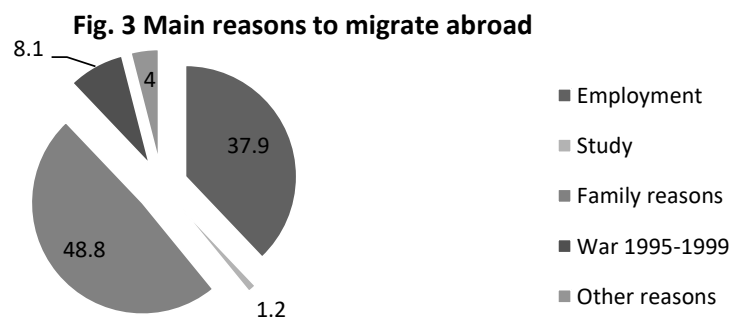

Source: Population census 2011 


\section{a. Countries where most of Kosovars migrate 2012/2013}

The largest number of immigrants is after 1999 with $52.1 \%$ of migrants, and most of them have migrated to Germany and Switzerland. Rural settlements are those that migrate the most. Average age of migrants is around 41 years. Countries where most of kosovars migrate are host countries such as, Germany, Switzerland, France, Slovenia, Austria, but some of them also live in the USA, Canada, Australia etc. A factor that has impact on remittances is the amendment of policies for immigration in migrant countries.

\section{b. Allocation of Remittances in Kosova and their effective treatment}

A factor which influences the identification of information is that the most of income sent in form of a remittance is sent as cash, and this is due to the high bank interest rates and commissions from money transfer institutions. Creation of a favorable environment to send remittances would be an advantage for correct statistical data. From Figure no. 4 we can see that $40 \%$ of immigrants' income is sent in Kosova in form of remittances, but their usage is still a challenge for Kosova's economy.

Fig. 4 Percentages of income from immigrants sent in Kosova

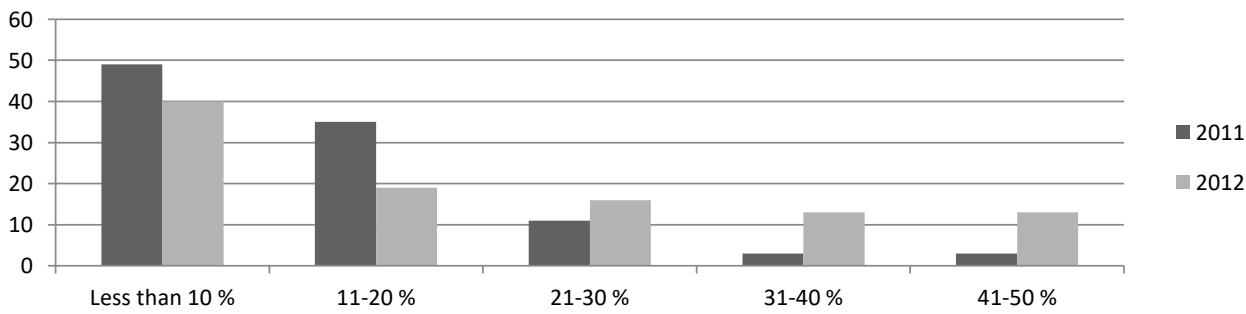

Source: Survey on remittances of family economies 2013'Kosova Agency of Statistics and UNDP

The best way of contribution from immigrants in sustainable economic development of the country would be for them to open new individual businesses, this way they could contribute in the increase of income for consumption, better social welfare for family economies, and at the same time contribute to a higher standard of living and economic development. Most of the businesses in Kosova are established through personal income, and least from different donations.

Total annual of remittances in cash sent from emigrants is considered to be 186.9 million Euro, whereas total annual spending of emigrants is 270.1 million Euro that count annual income from remittances in Kosova is 457 million Euro. A good way of promoting diasporas' investments would be through creation of consortiums with local businesses in Kosova, which has proven to be very successful in developed countries. Promoting of such projects and initiatives for effective treatment of remittances would have a great impact in Kosova's economy. Below we can see a distribution of remittances in godos and services, where we can notice a standoff in using the income for educational services and investments. Creation of a system for direct investments from remittances would help in better allocation of remittances. 
Fig. 5 Distribution of remittances in goods and services

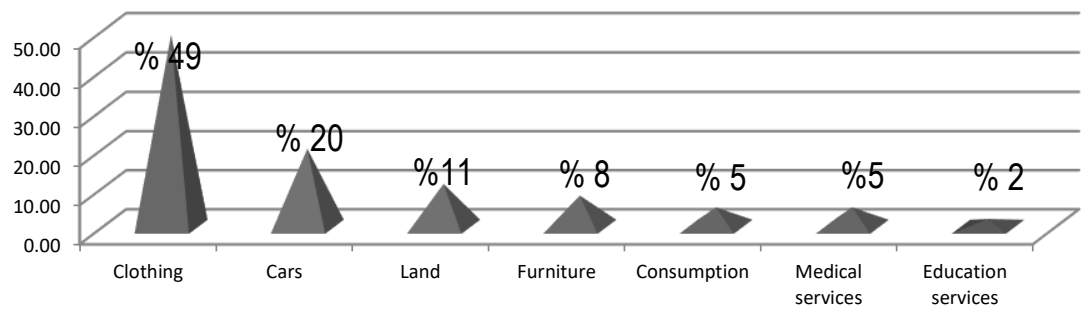

Source: Survey on remittances of family economies 2013'Kosova Agency of Statistics and UNDP

\section{Conclusions and Recommendations}

\section{Conclusions:}

- Kosova is very dependant on Remittances;

- High commissions and interest rates for remittances;

- Income from remittances are used the least for education services and investment;

- Income from remittances generate employment opportunities;

- Remittances impact on GDP growth \& reduction of unemployment rate;

- Difficulty in gathering correct data, due to the fact that most remittances are sent in cash;

- Risks from economic crisis in Western Europe, and amendments of immigration laws may affect remittances.

- How government uses its mechanisms to improve economic growth, creation of a favourable environment for investment, employment opportunities, and social welfare is of a huge importance.

\section{Recommendations:}

- Investment of income from remittances in educational services and establishment of entrepreneurship companies that generate new employment opportunities;

- Engaging Diaspora in Economic Development through investment;

- Initiation of Diaspora Investments in creating entrepreneurship opportunities;

- Government authorities to facilitate doing business in Kosova, by reducing or removing taxes, loan interest rates for start-up businesses;

- Promoting Projects/Initiatives/Investments with remittances as components;

- Since Kosova has a non sufficient budget for investments, it is considered that only direct investments can help Kosova to have a sustainable economy, so, the creation of favourable environment for investments is a must;

- Creation of effective fiscal policies to promote investments from diaspora;

- Organising of an International Conference for promotion of investments in Kosova by using different modalities and good practices from abroad;

- Introduction of a system for specific allocation of remittances in education;

- Introduction of a 'National Migration Information System', by offering correct and up to date statistics regarding migration;

- The promotion of Internal control over the migration of citizens.

\section{References}

[1] Central Bank of the Republic of Kosova (2008). Central Bank Annual Report

[2] Dilip Ratha, World Bank (2012-2014). Outlook for Migration and Remittances

[3] Koser K. (2007). International Migration: a very short introduction 
[4] Kosova Agency of Statistics dhe UNDP Kosova (2013). Housholds Surveys on Remmittances

[5] Kosova Agency of Statistics, Department of Statistics (2004-2012). Gross Domesitc Product on Expenditure Approach

[6] Kosova Agency of Statistics, Department of Statistics (2011). Estimation of Kosova Population

[7] Kosova Agency of Statistics, Department of Statistics (2011-2012). Economic Statistics

[8] Kosova Agency of Statistics, Department of Statistics (2012). Labour Force Survey in Kosova

[9] Stephen Castles and Mark Miller p.5 (2003). The Age of Migration

[10] UNDP, USAID (2010). Kosova Remittance Study

[11] World Bank (2011). Migration and Remittances, Factbook

[12] World Bank, Dilip Ratha (2012-14). Outlook for migration and remittances 